\title{
Integral Design in Architecture
}

\section{Integrální návrh v architektuře}

Lukáš Kohout

Fakulta architektury, České vysoké učení technické v Praze, Česká republika lukas.kohout@seznam.cz

\begin{abstract}
Integrated design is an approach to design that incorporates specialism in different fields that are usually considered as separate professions. Integrated design brings together methods that support specialists in different fields of design and construction. Due to the cooperation between the architects, engineers, owners and users involved in this process, a significant cost and resource reduction is achieved in construction. The cooperation described can often be found at large architectural businesses - we can find SIAL and GAMA in the Czech Republic (more specifically in Czechoslovakia); MVRDV, Behnisch Architekten and Transsolar in foreign countries.
\end{abstract}

KEYWORDS: integrated; design; process; architecture; IDP

ABSTRAKT: Integrální návrh je přístup k navrhování spojující dohromady profesní specializace, o kterých se běžně uvažuje separátně. Integrální návrh zahrnuje metody podporující specialisty z rozdílných profesních oblastí ve spolupráci za účelem vzniku integrovaného návrhu. Právě díky kooperaci jednotlivých profesí a také osob činných ve výstavbě již na samém počátku návrhu lze dosáhnout významných úspor nejen při výstavbě, ale hlavně při provozu budovy. Tuto spolupráci lze vysledovat ve velkých projekčních kancelářích - u nás to býval SIAL a Pragerova GAMA, v zahraničí jde například o velká studia jako Behnisch Architekten, MVRDV, Transsolar a další.

KLÍČOVÁ SLOVA: integrální; návrh; proces; architektura 


\section{Úvod}

V moderní době jsou jasně zřetelné tendence ke zvyšování komplexnosti budov. Nejedná se přitom o vyjádření komplexnosti ve smyslu prostorové složitosti a futuristických organických tvarů. Naopak, tyto expresivní formy často zakrývají interní složitost a propracovanost stavby, které nejsou na první a také vnější pohled zcela zřetelné. Vnitřní komplexnost takovýchto staveb je definována sofistikovanými technickými řešeními, inteligentními systémy pro udržování př́iemného vnitřního prostředí a také lidmi, kteří mají úplně jiné požadavky na to, co by dům měl poskytovat. Ve snaze vyhovět těmto novým konstrukcím, systémům a požadavkům je potřeba přijít také s novým př́istupem $\mathrm{k}$ navrhování domů.

\section{Integrální návrh}

Integrální návrh je iterativní proces, metoda nebo také př́stup k tomu, jak zpracovat komplexní návrh nebo činit rozhodnutí ohledně návrhu. Z této definice je jasně patrné, že je ho možno uplatnit ve všech odvětvích lidské činnosti, nejen v architektuře.

Dle iiSBE (1) vznikl v architektuře integrální proces návrhu po roce 1993, během kanadského programu C-2000 (2), který měl demonstrovat nová řešení v rámci návrhu a výstavby energeticky udržitelných a cenově nenáročných domů. Nicméně již v roce 1969 publikoval Reyner Banham knihu The Architecture of the Well-tempered Environment (3), ve které definuje dva možné prrístupy k řešení složitých systémů. První př́stup - „power-operated solutions“ (řešení řízená silou) - lze charakterizovat př́istupem „brute-force“ $\mathrm{k}$ řešení problémů, které se objeví během procesu návrhu. Toto řešení směřuje ke zvyšování složitosti, navyšování energetické náročnosti či přidávaní dalších konstrukčních vrstev. S ohledem na současné požadavky na energetickou úspornost a udržitelnost staveb je od tohoto přístupu postupně upouštěno. Druhým př́stupem je tzv. „structural solution“ (strukturální řešení), které se definuje jako spojení energie, konstrukce, architektonických záměrů a formy. $V$ tomto př́stupu lze nalézt podobnosti s př́stupem integrálního návrhu (Banham, 1969).

\section{Přístupy k navrhování a jejich porovnání}

K pochopení rozdílů mezi tradičním př́istupem a integrálním návrhem je potřeba definovat i tradiční prrístup k navrhování. Ten lze chápat jako čistě lineární proces, ve kterém vše začíná shodou architekta a klienta na velikosti, objemu a uspořádání domu. Teprve v druhé fázi se projekt předává specialistům, kteří do něj doplňují vnitřnosti - rozvody vody, elektřiny, ventilace a vytápění. V takovém prŕpadě však nelze dosáhnout současné optimalizace architektonického návrhu a technologických 
systémů. Z toho pak plynou běžné nedostatky, které lze nalézt u mnoha nových staveb, nap̌r. nedostatečné využívání solárních zisků během léta, zbytečný výkon chladicích systémů při nesprávném navržení a nesprávné orientaci skleněných prvků fasád a v neposlední řadě také nepohodlí uživatelů v prostorách se špatně navrženým zastíněním a zasklením. Všechny tyto chyby bývají přehlíženy, protože takovýto lineární proces bývá jednoduchý a rychlý, ale v konečném výsledku znamená velké nároky na provoz a údržbu, př́padně i úpravu v rámci řešení vnitřního prostředí. Ani takovéto úpravy a změny však nezaručí snížení náročnosti a většinou znamenají další finanční zatížení investorů. Na obrázku č. 2 je vynesen graf závislosti ceny na náročnosti změn a dosahu těchto změn a také průběh tradičního procesu návrhu.

Naproti tomu integrální návrh v sobě již ze svého principu spojuje komunikaci a spolupráci mezi architektem a inženýrem/specialistou. Tato spolupráce je navázána již $\mathrm{v}$ prvních fázích navrhování, a díky tomu je brána v potaz odbornost všech participujících. Architekt již není jediným aktérem, který o návrhu rozhoduje, ale i přesto si udržuje svoji pozici vedoucího týmu, moderátora. Zatímco on získává povědomí o technologických řešeních navržených spolupracujícími inženýry, inženýři naopak získávají vhled do komplexnosti architektonického návrhu. Z jejich pohledu to pak znamená vyšší míru zapojení do samotného návrhu než v př́ípadě konvenčního přístupu k navrhování. Stejně tak je vyžadována vyšší míra zapojení klienta.

Z definic je patrné, že ke změnám dochází i ve struktuře týmu, který projekt navrhuje. U tradičního př́stupu zůstává také tradiční schéma struktury. Klient si zvolí architekta, kterému komunikuje své požadavky na budovu, a architekt dodává veškeré potřebné výkresy a dokumenty. $\mathrm{K}$ tomu mu slouží skupinka specialistů, se kterými už má dobré zkušenosti a se kterými může pracovat dlouhodobě, tzn. na více projektech. Druhou možností jsou pak specialisté, kteří s architektem spolupracují pouze na daném projektu, např́ílad proto, že jsou na návrh kladeny specifické požadavky. $\mathrm{V}$ případě integrálního návrhu je přístup podobný, nicméně obohacený o další členy. V hlavním týmu již není pouze klient a architekt, ale jsou v něm i inženýr, statik, specialista na vnitřní prostředí, odborník na energetickou analýzu a mnohdy i dodavatel stavby. Tento tým spolupracuje na návrhu od samého začátku, a každý ze zúčastněných tak může do návrhu zasahovat a poskytovat cenné připomínky již ke konceptu. Výsledkem toho je vyvážený koncepční návrh, který již zahrnuje představu architekta o formě a analýzu prostředí a energetických poměrů stavby a okolí. V neposlední řadě je také zvoleno správné konstrukční řešení, které umožňuje splnění všech těchto požadavků. $\mathrm{V}$ dalším kroku se rozšiřuje celkový návrh a dochází k upřesňování systémů a podoby budovy. U všech rozhodnutí je však stále přítomen celý základní tým, který k sobě v př́ípadě potřeby může přizvat specialisty z dalších oborů, jako je například hydrogeolog, interiérový architekt, specialista na akustiku či světelnou techniku a mnoho dalších. 


\section{Závěr}

Tímto procesem vzniká ucelená, komplexní stavba s jasně nastavenými a vyřešenými parametry, která využívá synergie jednotlivých systémů a dosahuje mnohem větší efektivity v rámci spotřeby energie, náročnosti na údržbu, komfortu užívání a také udržitelnosti. Právě udržitelnost je jedním z hlavních důvodů, proč integrální návrh vznikl. Ve snaze minimalizovat náklady, a přitom udržet stejný komfort pro uživatele je potřeba přicházet se stále sofistikovanějšími řešeními, která už nejsou pouze záležitostí architektury či konstrukčního detailu. Na těchto řešeních se často podílí velké množství lidí z různých vědních oborů. A nejde přitom jen o věci technické. Do udržitelné architektury se často promítají i témata, která se dř́ive neřešila, např. socioekonomické otázky, otázky správy a údržby budovy, otázky certifikací a další. Pokud chce investor dosáhnout na kteroukoliv zelenou certifikaci BREEAM (4) nebo LEAD (5), je nutné, aby alespoň na nějaké úrovni využíval integrálního návrhu a jeho výhod oproti klasickému schématu návrhu. Na druhou stranu nelze ovšem říci, že pokud bude při návrhu použito integrálního návrhu, bude automaticky získán některý ze zmiňovaných certifikátů.

Architektura směřuje ke stále větší složitosti a lze očekávat, že se tento trend bude zrychlovat, ne zpomalovat. Je potřeba na tento trend reagovat a nezůstávat konzervativní. Cestou k uchopení této složitosti je právě integrální návrh. Podstatou integrálního návrhu není omezení architektury na úkor dalších profesí, ale posílení propojení architektonické formy a dalších systémů za účelem vzniku funkční, estetické a udržitelné stavby, která bude splňovat veškeré architektonické, socioekonomické, ekologické i správně-administrativní nároky, které jsou na ni kladeny.

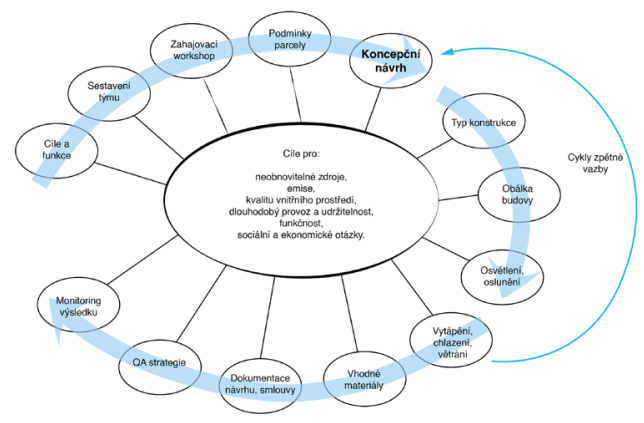

Obr. 1. Grafické zobrazení integrálního návrhu dle iiSBE (Zdroj: http://iisbe.org/ down/gbc2005/Other_presentations/IDP_overview.pdf, str. 4) 


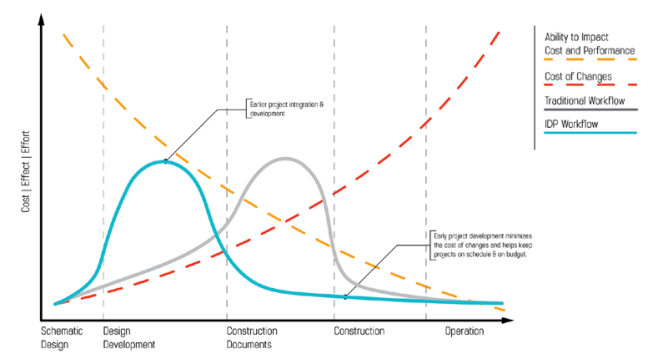

Obr. 2. Graf průběhu jednotlivých procesů a náročnosti změn v designu (Zdroj: http://www.popsci.com/building-information-modeling-how-construction-industry-getting-smart)

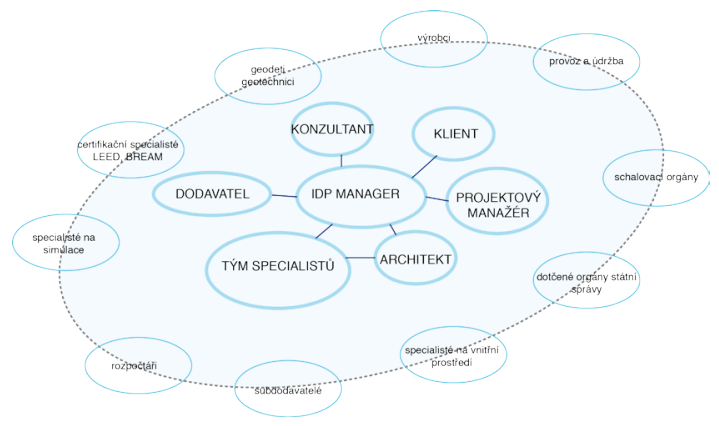

Obr. 3. Struktura týmu při integrálním návrhu (Zdroj: http://www.greenspacencr. org/events/IDProadmap.pdf, str. 26)

\section{Poznámky}

1. International Initiative for a Sustainable Built Environment, www.iisbe.org, v dokumentu z Green Building Challenge 2005 - The Integrated Design Process, dostupné z http://iisbe.org/down/gbc2005/Other_presentations/IDP_overview.pdf

2. http://www.iisbe.org/C2000/abc-2000.htm

3. BANHAM, Reynar, 1969. The Architecture of Well-tempered Environment. Chicago: The University of Chicago Press. ISBN 978-0226036984

4. Building Research Establishment Environmental Assessment Method, dostupné z http://www.breeam.com/

5. Leadership in Energy and Environmental Design, dostupné $\mathrm{z}$ http://www.usgbc.org/leed 


\section{Prameny}

ALDRICH, Rebekkah Smith, 2011. A Whole Systems Approach. Library Journal [online]. 15. 9., roč. 136, č. 15, s. 30-33. ISSN 03630277. Dostupné z: http://search.

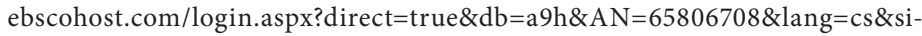
te=ehost-live

ALEX ZIMMERMAN A.SC.T., nedatováno. Integrated Design Process Guide [online]. B.m.: Canada Housing and Mortgage Corporation. Dostupné z: http:// www.infrastructure.alberta.ca/content/doctype486/production/leed_pd_appendix_7a.pdf

GRANADEIRO, Vasco, José P. DUARTE, João R. CORREIA a Vítor M.S. LEAL, 2013. Building envelope shape design in early stages of the design process: Integrating architectural design systems and energy simulation. Automation in Construction [online]. 7., roč. 32, s. 196-209 [vid. 2016-03-29]. ISSN 09265805. Dostupné z: doi:10.1016/j.autcon.2012.12.003

JØRGENSEN, M., M. W. NIELSEN a J. B. STRØMANN-ANDERSEN, 2011. Integrated Design - A paradigm for the design of low-energy office buildings. ASHRAE Transactions [online]. 5., roč. 117, č. 1, s. 230-239. ISSN 00012505. Dostupné z: http://search.ebscohost.com/login.aspx?direct=true\&db=a9h\&A$\mathrm{N}=67359315$ \&lang=cs\&site $=$ ehost-live

NILS LARSSON, 2005. The Integrated Design Process [online]. 2005. B.m.: International Initiative for a Sustainable Built Environment. Dostupné z: www.iisbe.org/ down/gbc2005/Other_presentations/IDP_overview.pdf

NILS LARSSON, 2009. The Integrated Design Process; History and Analysis [online]. 21. záŕí 2009. B.m.: International Initiative for a Sustainable Built Environment. Dostupné z: http://www.iisbe.org/system/files/private/IDP development - Larsson.pdf

NILS LARSSON a BART POEL, 2011. Solar Low Energy Buildings and the Integrated Design Process: An Introduction [online]. 1. červen 2011. B.m.: Public Works and Government Services Canada. Dostupné z: http://www.tpsgc-pwgsc.gc.ca/biens-property/sngp-npms/conn-know/enviro/pci-idp-eng.html

BANHAM, Reynar, 1969. The Architecture of Well-tempered Environment. Chicago: The University of Chicago Press. ISBN 978-0226036984. 